\title{
On the occurrence of the fungus Lentinus lepideus Fr. on railway sleepers in Finland
}

\author{
Juha Suominen \\ Department of Botany, University of Helsinki, Unioninkatu 44, \\ SF-00170 Helsinki 17, Finland
}

\begin{abstract}
Lentinus lepideus is common on Finnish railway sleepers made of pine wood. Of the 280 railway stations studied, its fruit bodies were observed at 156 stations, which were fairly evenly distributed over the railway net. There is some concentration on less used and poorly maintained lines. Railway age and station size have little influence. During the observation period of five years no yearly differences in the occurrence were noted. Fruit bodies emerge at the end of June, and their number remains almost constant up to September.
\end{abstract}

While carrying out botanical field work in 1963 - 67 on Finnish railways (so far treated in Suominen $1969 \mathrm{a}$ and b), I made some notes on the fungi of the wooden railway sleepers. These observations relate almost exclusively to one single species, the lamellate macrofungus Lentinus lepideus Fr.

This species is known to have specialized on railway sleepers, and in Finnish handbooks it is named 'ratapölkkysieni' = the 'railway sleeper fungus'. Besides my own collections, there are six specimens from railway sleepers in $\mathrm{H}$. Lentinus lepideus is listed (Benito Martinez 1963: 66-67) among the most important railway sleeper fungi of Spain, France, England, Belgium, Germany and Sweden, being recorded from more countries than any of the other fungi. It is also common in Canada (Groves 1962: 161), often occurring on railway sleepers and causing serious rotting. Besides railways, it occurs on wooden bridges, posts and mine props, and on pine stumps in nature. Writing of the species in Finland, at a time when railways were still new and limited in extent, KARSTEN (1876: 234) reports: »Ad ligna Pini vereautumno. In regionibus borealibus sat frequens, in australibus rarior.» The scarcity of herbarium specimens from Lapland is evi- dently due only to inadequate collecting; the species occurs up to Inari Lapland (Kallio \& KanKainen 1964: 191).

In forests Lentinus is of minor importance as a decomposer of wood, whereas it causes serious damage to railway sleepers. The following circumstances make sleepers (and posts, etc.) particularly suitable substrates for Lentinus:

1) Finnish railway sleepers are made of Pinus sylvestris L., and Lentinus lives in pine wood (and in Larix; KöNIG 1957: 251).

2) The fungus needs considerable moisture (KöNIG, loc. cit.) and this is often found in wood in contact with the soil.

3) The optimal growing temperature of Lentinus is high, ca. $27^{\circ} \mathrm{C}$ (information received from 'Lahontorjuntayhdistys r.y.', the Finnish association for the control of wood rot), and dark sleepers lying in open railway yards and track beds certainly become warm on sunny days.

4) For sleepers old, slow-growing pine trees with a large proportion of hard, reddish, resinous heartwood are preferred. Lentinus is a specialist of heartwood (KöNIG, loc. cit.).

5) Heartwood cannot be completely impregnated with wood preservatives, and Lentinus spores can penetrate through the im- 
pregnated sapwood, falling or being washed by rain down deep clefts arising in the wood during drying.

6) Lentinus is particularly resistant to coal tar creosote. According to information from the State Railways and Lahontorjuntayhdistys r.y., creosote oil is used in Finland at the rate of $80-90 \mathrm{~kg} / \mathrm{m}^{3}$ sleepers (ca. $8-9 \mathrm{~kg}$ / sleeper), and ca. $18 \%$ of the ca. 13 million sleepers are unimpregnated (1970). As much as ca. $100 \mathrm{~kg}$ creosote oil $/ \mathrm{m}^{3}$ (Becker 1972) is needed to give adequate protection against Lentinus. Benito Martinez (1963: 65) cites instances of Lentinus tolerating up to 24$30 \mathrm{~kg} / \mathrm{m}^{3}$. Thus Lentinus is able to develop on the sleepers when insufficient creosote oil has been applied or some evaporation has taken place. The fungus is probably also able to cause chemical alterations in fungicides (Benito Martinez, loc. cit.).

Nearly all my observations were made at stations, in railway yard areas. Little attention was paid to railway lines between stations. Lentinus does occur there as well but since the sleepers are changed more frequently and are in better condition, the species, or at least its fruit bodies, concentrates on the less used sidings in railway yards, where older sleepers are found. At $31 \%$ of the 156 stations with Lentinus, the fungus was very sparse, being noted on 1 to 2 sleepers, at $53 \%$ it was sparse to moderately sparse, occurring on 3 to 5 sleepers, at $10 \%$ it was found on 6 to 10 sleepers, and at $6 \%$ on more than 10 sleepers, in a few cases up to $30-50$ (Fig. 2). The number of fruit bodies

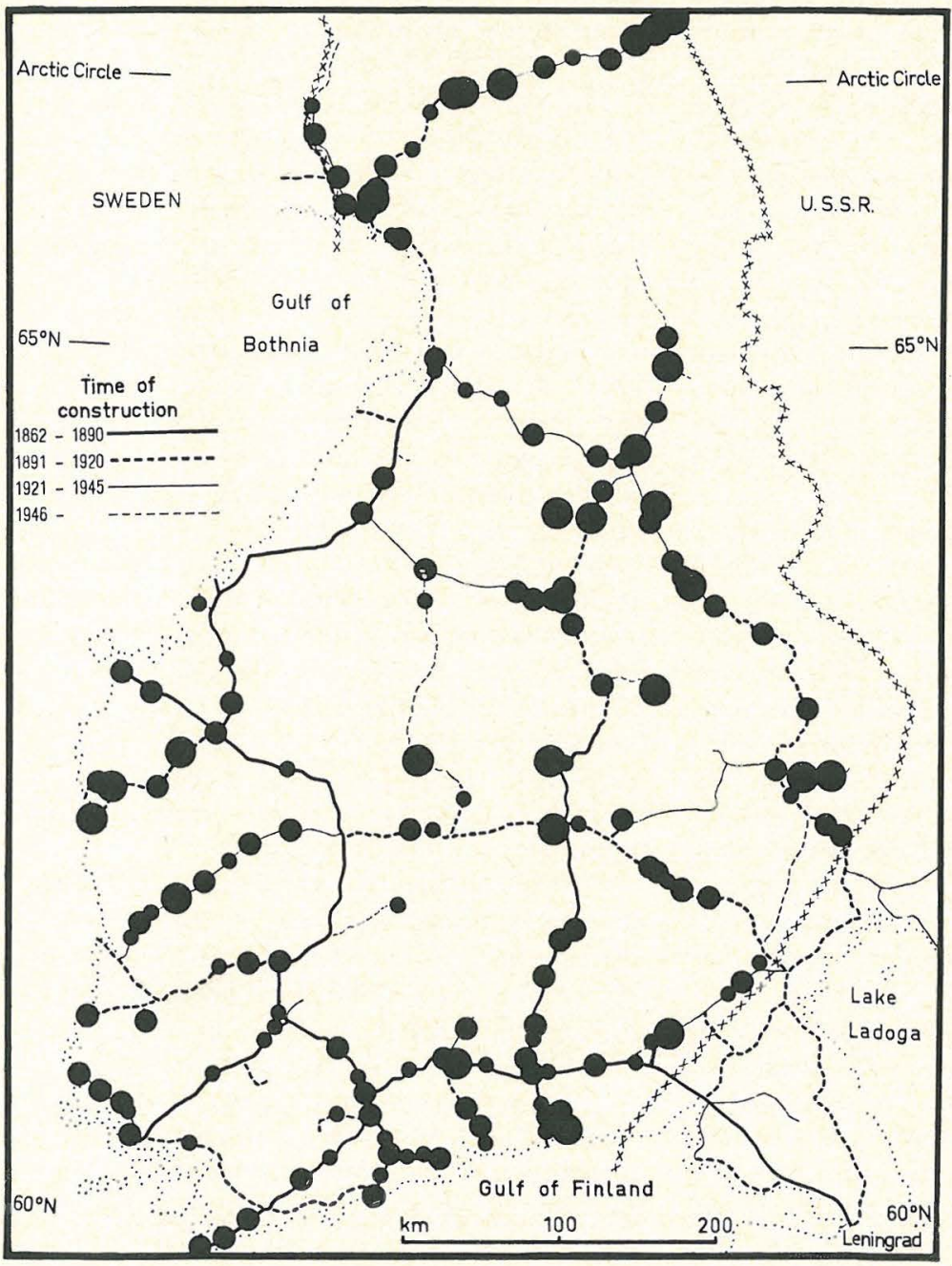

Fig. 1. Distribution of Lentinus lepideus on the Finnish railway net: noted at 156 stations out of the 280 studied. The size of dots indicates abundance, according to the scale given in Fig. 2. 


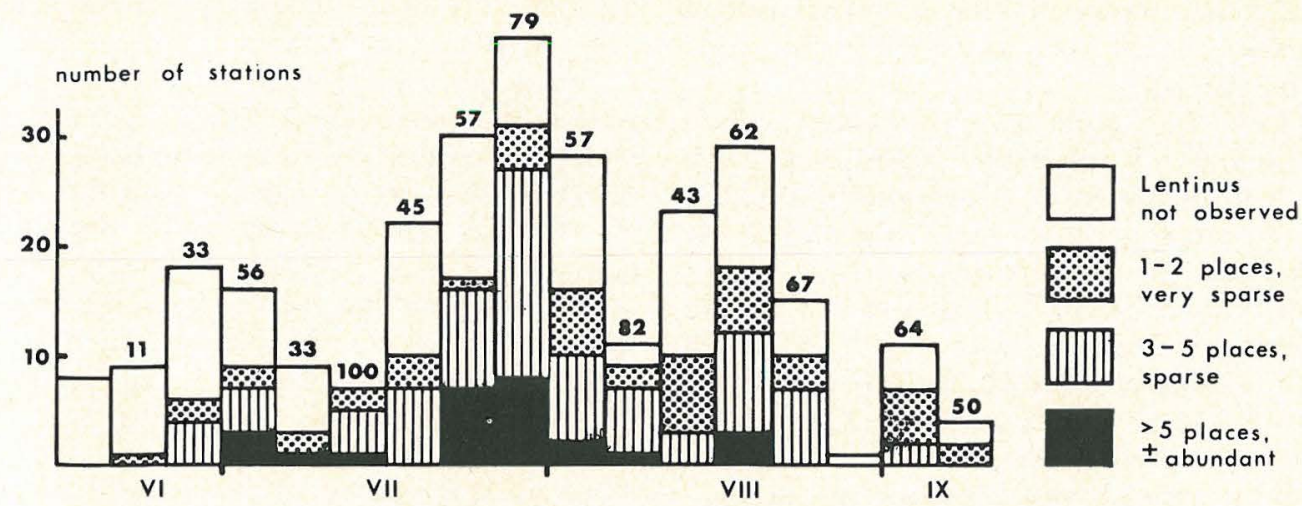

Fig. 2. Occurrence of Lentinus lepideus on the 280 railway yards studied in 1963 - 67, in 5-day periods. The percentage of stations with Lentinus is given above each of the columns for 5-day periods.

on one sleeper varied from 1 to ca. 5. Usually all the fruit bodies protruded from a single point or along a short portion of a major cleft in the sleeper, on its upper surface or sometimes close to the soil surface. As a rule, all the fruit bodies on the same sleeper seemed to be of the same age. The fruit body persists for some time, probably several weeks. Its age is much determined by insect larvae, which frequently occur in abundance and eat it up. More or less hollow, dry remains of fruit bodies sometimes persist for a long time. These are included in the records, and this fact must be borne in mind when the phenology of the species is considered.

Of the 280 railway stations studied, which were evenly distributed over the Finnish railway net, Lentinus was observed at 156 $(55.7 \%)$. Its distribution is rather homogeneous (Fig. 1). However, it shows some tendency to avoid the busiest and best maintained main lines, where improvements have often recently been made. The abundant occurrences, in particular, tend to concentrate on the more remote lines, lying largely in the north and northeast. Like its distribution over the railway net, its general distribution in Finland is evidently also rather uniform.

The size of the railway stations seems to have little influence on the occurrence of Lentinus. If all the stations are arranged in six groups, in descending order of size, the percentage occurrence in the groups is 77 , $58,50,44,60$ and 50. The larger areas and numerous sidings of the large stations are apparently counterbalanced by the concentration of the small stations on infrequently used poorly maintained lines.

The occurrence of Lentinus at stations on old railway lines (cf. Fig. 1) was not higher than average $(52 \%$ for the oldest, $53 \%$ for the second group) although it might be thought that the density of the fungus and opportunities for its establishment would increase over the years. The third age group, viz. stations on railways constructed during $1921-45$, shows as high a frequency as $75 \%$ and many rich occurrences of Lentinus. This group includes a high proportion of more poorly maintained and remote lines. The small group of stations (28) on lines constructed from 1946 onwards has a frequency of $39 \%$ only. Nevertheless, at some of these stations Lentinus achieved rich occurrences within about ten years: Otanmäki 12 years, Juankoski 9, Heinävaara and Tuupovaara 8, Saarijärvi 4 years. At least in the last case some years must be added, because the periods are calculated from the year of opening of the railway line in question.

The percentage of stations at which Lentinus was found in each of the five study years (1963 - 67) remained fairly constant: $53,49,57,61$ and $80 \%$. The high number of stations studied in June in 1964 is responsible for the low value for that year, and only 25 stations were studied in 1967.

Differences can be distinguished in the occurrence of Lentinus during the course of the summer (Fig. 2). The first fruit bodies do not seem to emerge until the last week of 
June. From this time on, they are found throughout the summer up to September. The fact that the frequency and particularly the abundance of the occurrences fluctuate within very narrow limits from the end of June onwards suggests that either all the fruit bodies develop at more or less the same time and persist for the rest of the summer, or their emergence and complete disappearance balance each other throughout the summer. The former alternative is supported by the considerable age attained by the fruit bodies and by the long time during which the hard, dried and/or partly eaten fruit bodies can be noted. I regret that no records were made on the age and condition of the fruit bodies. The data on the labels of the herbarium specimens (in $\mathrm{H}$ ) agree with the above observations in that the bulk of the specimens were collected in July-September, the few collected in June being taken towards the end of that month. The specimens of June and July are rather young and healthy, those of a later date mainly old and degenerated, and often evidently already dried up when collected.

Gloeophyllum sepiarium (Wulf. ex Fr.) Karst. (Lenzites sepiaria Wulf. ex Fr.) was collected at two stations; it is given (Benito Martinez 1963) as an important fungus of Norwegian railway sleepers. The few other species encountered were collected only once.

A list of the railway records of Lentinus lepideus is deposited in the Mycological Herbarium of the University of Helsinki $(\mathrm{H})$.

Acknowledgements. I am much indebted to Mr. U. Tuovinen, M.Sc., of Lahontorjuntayhdistys r.y. for supplying literature and other information. Mrs. Anna A. Damström, M.A., corrected the English.

\section{LITERATURE:}

Becker, G., 1972: Kreosootin aineosien ja sen lahosuojausominaisuuksien muuttumisesta kreosoidun puutavaran vanhetessa. (Finnish summary of a lecture.) - Lahontorjunta 1972 (1): 10-13. Vammala.

Benito Martinez, J., 1963: Die wichtigsten, Schwellen angreifenden Pilze und die Entwicklung der Schwellenimprägnierung in Spanien. - Pp. 65-73 in Holzschwellenhandbuch. 232 pp. Haag.

Groves, J. W., 1962: Edible and poisonous mushrooms of Canada. $x+298$ pp. Ottawa.

Kallio, P. \& E. Kankainen, 1964: Notes on the macromycetes of Finnish Lapland and adjacent Finnmark. - Ann. Univ. Turkuensis, ser. A II 32 (Reports Kevo Subarctic Research Sta. 1): $178-235$.

Karsten, P. A., 1876: Mycologia Fennica. Pars tertia, Basidiomycetes. - Bidrag Kännedom Finl. Natur Folk 25: $x+1-377$.

KönIG, E., 1957: Tierische und pflanzliche Holzschädlinge. - 330 pp. Stuttgart.

Suominen, J., 1969 a: The plant cover of Finnish railway embankments and the ecology of their species. - Ann. Bot. Fennici 6: 183235.

—— $1969 \mathrm{~b}$ : The vegetation of railway yards and adjacent storage areas in Finland. - Ann. Bot. Fennici 6: 353-367. 